\title{
Dry port location optimization to foster sustainable regional development
} Otimização locacional de portos secos para fomentar o
desenvolvimento regional sustentável

Marlon Fernandes de Souza ${ }^{a}$ Paulo H. Góes Pintob

Raphael B. Alves Teixeirac

Carla de O. Leite Nascimento ${ }^{d}$

Rodrigo A. de Albuquerque Nóbrega ${ }^{e}$

aUniversity of Campinas (UNICAMP), School of Agricultural Engineering, Campinas, SP, Brazil. E-mail: marlonfernandesdesouza@gmail.com

${ }^{b}$ Federal University of Minas Gerais (UFMG), School of Engineering, Belo Horizonte, MG, Brazil. E-mail: paulo-goes@ufmg.br

'Federal University of Minas Gerais (UFMG), School of Engineering, Belo Horizonte, MG, Brazil. E-mail: teixeiraraph@outlook.com

${ }^{d}$ Federal University of Minas Gerais (UFMG), School of Engineering, Belo Horizonte, MG, Brazil. E-mail: carla.oln@gmail.com

${ }^{e}$ Federal University of Minas Gerais (UFMG), Geosciences Institute and School of Engineering, Belo Horizonte, MG, Brazil.

E-mail: raanobrega@ufmg.br

doi:10.18472/SustDeb.v11n2.2020.27073

\section{ABSTRACT}

The saturation of hinterland accentuates adverse environmental impacts and socio-spatial conflicts, demanding logistical alternatives. As a solution, the dry port enables the decentralization of customs, handling, and storage operations, which mitigates part of the problems, in addition to stimulating the economy in the region where it operates. Thus, its location is crucial for the efficiency of import and export logistic systems. This paper aimed to evaluate the spatial distribution of dry ports in Minas Gerais, Brazil, and to identify the best locations for a new installation. The methodology put together two recognized methods for location definition: the Spatial Multicriteria Analysis and the Location-Allocation Problem. The first, in line with the most current practices in transportation planning, integrated social, environmental and technical criteria. The second adopted the first's result as weighted demand and applied a metaheuristic to solve an optimization problem. Findings show the regional disparity and the deficiency of logistic infrastructures in the north of Minas Gerais. All scenarios point to the Montes 
Claros region as a candidate for the installation of a dry port. The possibility of reconciling society, environment and economy in infrastructure planning was demonstrated.

Keywords: AHP. Transportation Planning. Sustainable Regional Development. Inland Port. Location-Allocation.

\section{RESUMO}

A saturação das zonas de influência portuária acentua impactos ambientais e conflitos socioespaciais, demandando alternativas logísticas. O porto seco possibilita a descentralização de atividades aduaneiras, de manuseio e armazenagem, mitigando parte dos problemas, além de estimular a economia na região onde é inserido. Dessa forma, a sua localização é crucial para a eficiência dos sistemas logísticos de importação e exportação. O objetivo deste trabalho foi avaliar a distribuição espacial dos portos secos em Minas Gerais e identificar os melhores locais para uma nova instalação. A metodologia agregou dois métodos reconhecidos de definição locacional: a Análise Multicritério Espacial e o Problema de Localização-Alocação. O primeiro, em consonância com as práticas mais atuais no planejamento de transporte, integrou critérios sociais, ambientais e técnicos. O segundo, adotou o resultado da análise multicritério como demanda ponderada e aplicou uma meta heurística para solução do problema de otimização. Os resultados evidenciam a disparidade regional e a deficiência de infraestruturas logísticas no norte de Minas. Todos os cenários apontam a região de Montes Claros como candidata à instalação de um porto seco. A possibilidade de conciliar sociedade, ambiente e economia no planejamento de infraestrutura foi demonstrada.

Palavras-chave: AHP. Planejamento de Transportes. Desenvolvimento Regional Sustentável. Estação Aduaneira Interior. Localização-Alocação.

\section{INTRODUCTION}

Globalization was responsible for growth in commercial operations around the world with a consequent increase in the movement of goods and tax procedures for imports and exports. This high demand scenario for cargo transportation has saturated the ports and affected the costs of the international trading operation (GERMANO; FREIRE JUNIOR, 2017; NG; PADILHA; PALLIS, 2013). In addition to the economic and bureaucratic losses, the saturation of the seaport hinterlands intensifies the environmental impacts and socio-spatial conflicts (AWAD-NÚÑEZ et al., 2016a).

As for the environmental standpoint, the construction or even the expansion of a seaport invariably affects the local ecosystem. The ecological impacts are amplified as most seaports are located in estuaries (DINWOODIE et al., 2012; GOULIELMOS, 2013). Sinay, Carvalho and Braga (2017), Oliveira et al. (2013), and Jaffee (2015) report a series of social and environmental impacts related to the port operation. In addition, Sinay, Carvalho and Braga (2017) affirm the principal consequences of a port operation comes from the supplementary activities in the port vicinity where the overlapping areas of influence and the intensity of the activities produce cumulative and synergistic effects (KOEHLER; ASMUS, 2010).

In Brazil, the situation is even worst due to the elevated growth of exports experienced along the last decades in association with the deficient conservation of the existing logistic infrastructure and the lack of investments in new infrastructure (CHINELATO; CRUZ; ZIVIANI, 2011; MEDEIROS, 2014; WANKE; HIJJAR, 2009). Between 2010 and 2018 the port activity in Brazil increased by 33.2\% (ANTAQ, 2018). Limiting space for the growth of yards and warehouses is a reality for most Brazilian seaports, which increases truck traffic on highways and long queues for loading and unloading in port cities (GERMANO; FREIRE JUNIOR, 2017).

In this context the dry ports (DP) emerge as an alternative, acting as facilitators for storage, customs clearance, consolidation, and handling of cargo. (AWAD-NÚÑEZ et al., 2016b; GERMANO; FREIRE JUNIOR, 2017). Thus, the DP can be understood as intermodal land terminals strongly connected to seaports through a frequent and/or a high capacity transport service (NGUYEN; NOTTEBOOM, 2016; ROSO; WOXENIUS; LUMSDEN, 2009). In practice, a DP operates as logistic hinterlands, i.e. an inland 
region lying behind a port to facilitate moving cargo between the seaport and the interior with improved performance (LOUREIRO; FREITAS; GONÇALVES, 2015).

The decentralization of part of the seaport activities stands out among the main advantages of a $\mathrm{DP}$, since it brings the customs activities closer to the cargo's origin or destination. Other than the enhanced logistic solutions, DP also drives revenue and job creation in the region where it operates. Moreover, it creates the possibility to continuously release imports and exports over time, distributing customs expenses evenly during the financial year instead of a single large payment. Roso, Woxenius and Lumsden (2009) also highlight the DP reinforces the changing from road transportation to a more efficient and environmentally friendly transportation mode.

With this in mind, the objective of this paper was to assess the spatial distribution of the DP in Minas Gerais - Brazil, therefore indicating the best-feasible sites for proposing new DP in the state. The methodology that supported the analysis integrated two well-known methods used for geospatial location: the Spatial Multi-Criteria Analysis (SMCA) (LIGMANN-ZIELINSKA; JANKOWSKI, 2014; RAHMAN et al., 2013; SADASIVUNI et al., 2009) and the Location-Allocation Problem (LAP) (HILLSMAN, 1984; LORENA et al., 2001; MAPA; LIMA, 2012). The first can be understood as an integrating solution with distinct objectives, often conflicting (SAATY, 2008). The second is characterized as an application of the p-median problem, being widely used in the location of logistics facilities (LORENA et al., 2001).

Strategically, the study was conducted in Minas Gerais because it is an inner country state with great logistical and economic importance in Brazilian foreign trade and with no direct access to seaports. Thus, the state presents an interesting condition for the viability of a distant DP, where the distance and the size of the goods flow make the railroad viable under a strict cost perspective (ROSO; WOXENIUS; LUMSDEN, 2009). Indeed, the investigation considered the interregional inequalities of the state and the concept of Sustainable Social Economic Development (SSED), presented in the Minas Gerais Integrated Development Plan (MINAS GERAIS, 2015). This enlarged the traditional perspective of transportation planning beyond the logistical and economic aspects, and including also social and environmental ones.

\section{CHARACTERIZATION OF THE STUDY AREA AND CRITERIA SELECTION}

The state of Minas Gerais presents high biophysical, socioeconomic, and cultural heterogeneity, which reflects on the unbalanced spatial distribution of public equipment and transportation infrastructure. Figure 1 illustrated the study area by presenting the mesoregions, railways, state and federal roads, and the existing DP.

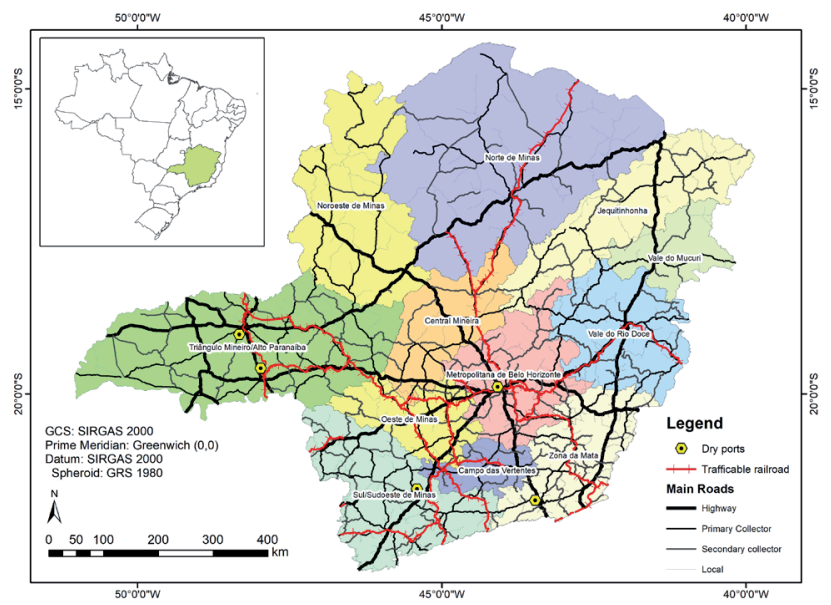

Figure 1 | Study site: Minas Gerais state's mesoregions overlaid by the existing dry ports, roads and rails in 2016 according to the Brazilian Institute of Geography and Statistics (IBGE) database.

Source: Authors' elaboration based on IBGE (2018) and Brasil (2014) data. 
The choice of the sites for new DP considered five criteria (environmental, competition, economic, logistics, and social aspects), four of them considered sub-criteria as presented in Table 1. The criteria were chosen upon specialized literature concerning the location of logistic facilities such as in Barboza and Vieira (2014); Bolturk et al. (2016); Ka(2011); Loureiro, Freitas and Gonçalves (2015); Nguyen and Notteboom (2016); Roso, Woxenius and Lumsden (2009); Sopha et al. (2016). Other criteria, such as legal aspects, the stability of the political scenario, construction costs, as well as engineering aspects are also reported in the literature (BOLTURK et al., 2016; ROSO; WOXENIUS; LUMSDEN, 2009). However, these aspects were not considered since they are not directly assigned to the spatial questions related to the scope of the investigation.

Regarding the logistic accessibility, the road network of Minas Gerais is the most extensive among the Brazilian states. Besides the unequal distribution, over $50 \%$ of the federal highways in southeast Brazil are in Minas Gerais (CNT, 2018). As for the railroads, the state has the second-longest network in the country (MINAS GERAIS, 2015).

Table 1 | Criteria, input data, data source, and method used to convert data for the geospatial model.

\begin{tabular}{|c|c|c|c|c|c|}
\hline Group & Criterion & Data Source & Year-base & $\begin{array}{l}\text { Original Data } \\
\text { Format }\end{array}$ & Spatialization Method \\
\hline \multirow{4}{*}{ Economic } & Exports FOB price & MDIC & 2015 & Tabular & Interpolation (IDW) \\
\hline & Imports FOB price & MDIC & 2015 & Tabular & Interpolation (IDW) \\
\hline & Number of jobs & RAIS & 2010 & Tabular & Interpolation (IDW) \\
\hline & GDP & FGV & 2015 & Tabular & Interpolation (IDW) \\
\hline Competition & $\begin{array}{l}\text { Avoid existing dry } \\
\text { port }\end{array}$ & PNLT2010 & 2010 & Vector - Point & Euclidian Distance \\
\hline \multirow{3}{*}{ Logistics } & Highway distance & $\begin{array}{l}\text { DEER/ } \\
\text { SETOP }\end{array}$ & 2015 & Vector - Line & Euclidian Distance \\
\hline & $\begin{array}{l}\text { Main road } \\
\text { distance }\end{array}$ & $\begin{array}{l}\text { DEER/ } \\
\text { SETOP }\end{array}$ & 2015 & Vector - Line & Euclidian Distance \\
\hline & Rail distance & PNLT2010 & 2010 & Vector - Line & Euclidian Distance \\
\hline \multirow{2}{*}{ Social } & $\begin{array}{c}\text { Non-employed } \\
\text { people }\end{array}$ & IBGE & 2010 & Tabular & Interpolation (IDW) \\
\hline & Social Index & $\begin{array}{l}\text { Atlas } \\
\text { Brasil }\end{array}$ & 2010 & Tabular & Interpolation (IDW) \\
\hline \multirow{3}{*}{ Environmental } & Avoid urban area* & $\begin{array}{l}\text { Embrapa } \\
\text { Territorial }\end{array}$ & 2015 & Vector - Polygon & Euclidian Distance \\
\hline & $\begin{array}{c}\text { Avoid hydrography } \\
\text { PPA** }\end{array}$ & IBGE & 2015 & Vector - Line & Euclidian Distance \\
\hline & $\begin{array}{l}\text { Avoid buffer zone } \\
\text { of CUs*** }\end{array}$ & $\begin{array}{l}\text { ICMBio/ } \\
\text { SEMAD }\end{array}$ & 2015 & Vector - Polygon & Euclidian Distance \\
\hline
\end{tabular}

*Influence zone limited to $5 \mathrm{~km}$ away from the urban areas.

**Despite the Act № 12.651 of May 25, 2012, that created the new Brazilian Forest Code (BRASIL, 2012) says the Permanent Protection Areas (PPA) of riparian forest must be protected by a maximum buffer of 500 meters, in this investigation we used a decaying gradient until 1000 meters as a conservatory polity to avoid proposing infrastructure in environmentally sensitive areas nearby rivers.

***Although CONAMA revoked CONAMA Resolution 13/1990 (BRASIL, 1990) in 2010, shrinking the 10,000 meters buffer zone for Conservation Units (CUs) without a management plan at to 3,000 meters, we adopted a buffer of 10,000 m considering the importance of these zones for the ecosystems surrounding the Conservation Units.

Source: Primary research data with the respective data source in the table.

The mining industry, in special the iron ore represents a significant share of the state's export revenue $(29 \%)$, with logistics infrastructure, supported by dedicated railroads and pipelines, highly efficient. However, other commodities also play important roles in the state's economy, therefore the exportation activities that can directly or indirectly benefit from strategically located DP. Other than iron ore, the main products exported are raw grained coffee $(12 \%)$, soybean grains and meal $(8.5 \%)$, and industrialized iron-alloys (8.0\%) (BRASIL, 2018). 
The imports of the state are more fractional, with emphasis on fertilizers or chemical fertilizers (8.9\%), coal $(7.7 \%)$, chemical compounds $(4.6 \%)$ and other products from the manufacturing industry $(4.3 \%)$ (BRASIL, 2018). To measure exports and imports, the Free-On-Board (FOB) price was applied to the municipalities considering the year-base 2015, as reported by the Brazilian Ministry of Industry, Foreign Trade, and Services (MDIC). The Gross Domestic Product (GDP) and the number of jobs related to the segments of mineral extraction, processing industry, agriculture, and public utility industrial services, from the Annual Catalogue of Social Information (Relação Anual de Informações Sociais - RAIS), were integrated to represent the economic activity.

As for the environmental characteristics, in 2010 the preserved natural areas corresponded to $6.4 \%$ of the state's territory. The Atlantic Forest, which originally covered up to $46 \%$ of the state, currently reaches $5.3 \%$ of the territory (MINAS GERAIS, 2015). Thus, there is a real need for investments in infrastructure that neither accentuate environmental impacts nor jeopardize the already scarce preserved areas.

Concerning social characteristics, the northern municipalities present the worst rates of the state, with per capita income below the average, as well as way below the Human Development Index (HDI) (MINAS GERAIS, 2015). Despite the Northwest, North, Jequitinhonha, and Mucuri mesoregions altogether hold $15.6 \%$ of the state's population, the block represents only $7.4 \%$ of the state's GDP (IBGE, 2012).

The indicator of non-employed people was obtained from Table 3580 pulled from System of Automatic Recovery (SIDRA) of the Brazilian Institute of Geography and Statistics (IBGE), which uses the 2010 Census Database (IBGE, 2012). The Social Index (SI) was proposed in this investigation to consider, in addition to the demand for port services, the potential for the socioeconomic regional impact of the DP. SI is proportional to the population and inversely proportional to the square of the HDI as shown in Equation 1.

$$
S I=\frac{P o p}{H D I^{2}}
$$

Where: HDI: Human Development Index (Atlas Brasil/Censo of 2010)

Pop: Population as reported by Atlas Brasil (PNUD; FJP; IPEA, 2013)

Due to their nature, each criterion presents a different unit. To allow comparison and integration, the criteria have been standardized. The values range from 0 to 10, where zero (0) represents the absence of influence of the variable, one (1) represents the lowest cost, and 10 the highest. The lower the value, the greater the attractiveness of the region for installing a DP.

As a key condition to the proposed investigation, the criteria were georeferenced using the methodology as indicated in Table 1. Due to the geographic nature of the spatial analyzes and the geographic dimension of the study area, all maps were set to equidistant conical projection to minimize cartographic distortions in distance measurements (MITCHEL, 2005; SNYDER, 1987).

\section{METHODOLOGY}

The methodology integrated, in a sequential way, two well know methods of location into a single model. Thus, the inverse of the index resulting from SMCA was used as weighted demand into the LAP, as illustrated in Figure 2. The selected scenarios enabled to assess the location of the existing DP and also the impact of socio-environmental prioritization when choosing the location of a new facility. 


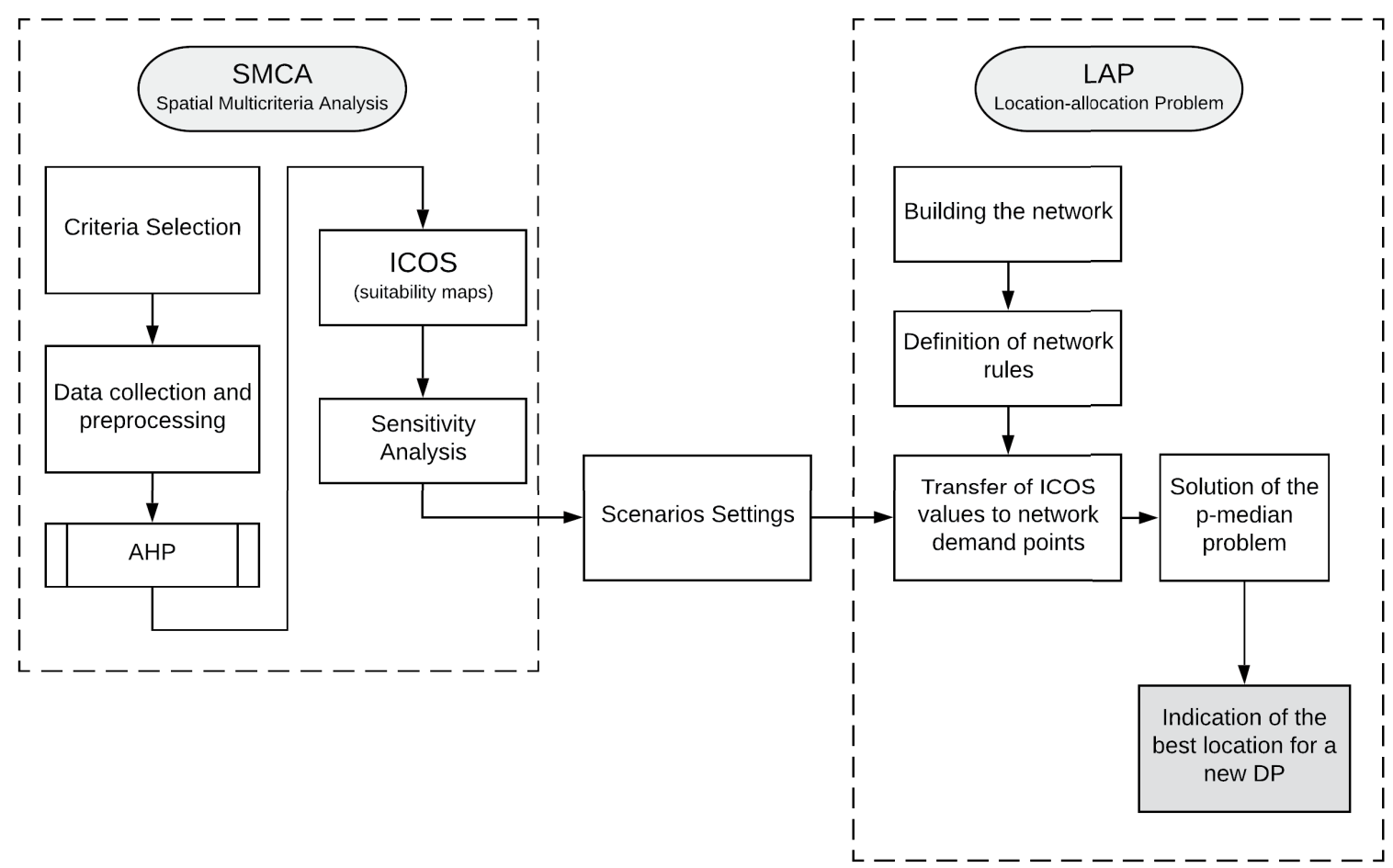

Figure 2 | Representative flowchart of the main methodological steps.

Source: Authors' elaboration.

\subsection{SPATIAL MULTI-CRITERIA ANALYSIS (SMCA)}

The hierarchy and the weights of the criteria were assigned following the Analytic Hierarchy Process (AHP) method (SAATY, 1977, 2008). The investigation counted with 10 experts in logistics that pair-wise evaluated the criteria. A spreadsheet developed by Goepel (2013) was used to perform the calculation. The weight value of each criterion (wi) was defined by the eigenvector of the largest eigenvalue $(\lambda)$ of the paired comparison matrix (CHEN; YU; KHAN, 2010; SAATY, 1977). The resulting hierarchy of criteria is illustrated in Figure 3.

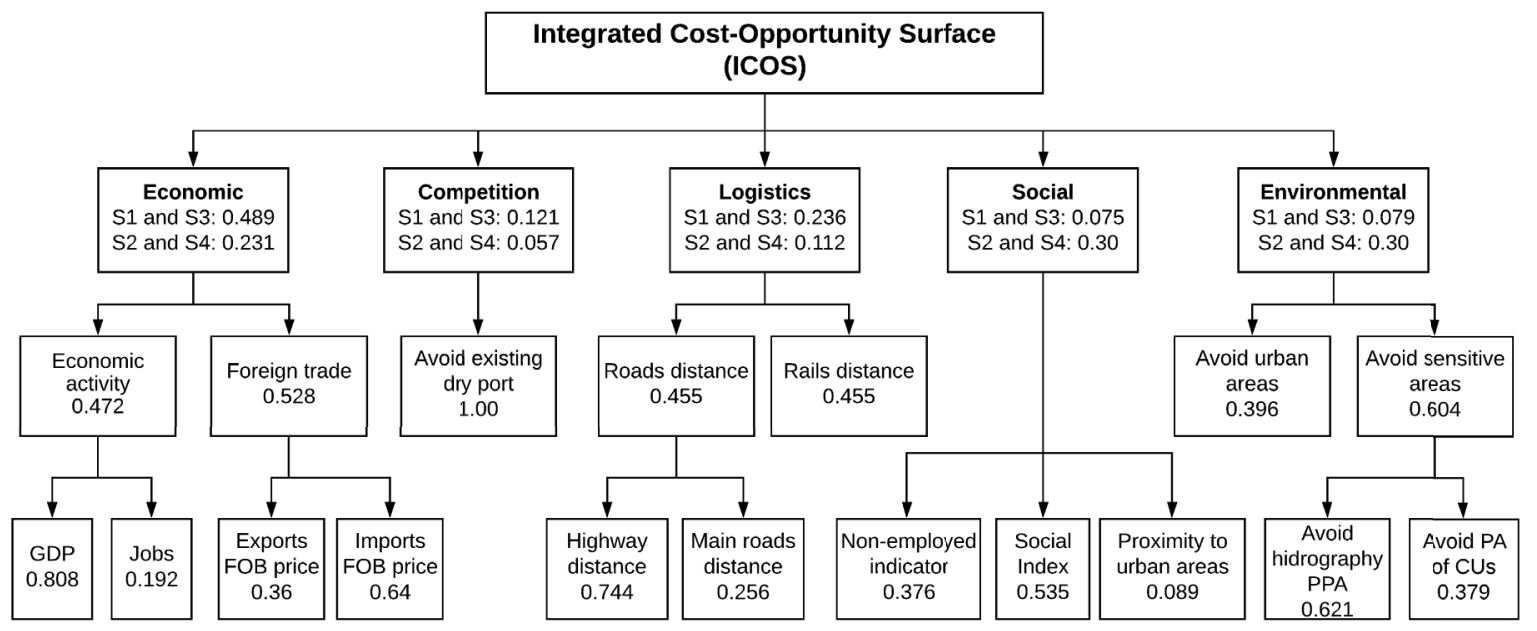

Figure 3 | Hierarchy of the criteria and the respective weights used in the Spatial Multi-Criteria Analysis (SMCA).

Source: Authors' elaboration. 
In order to assure the quality of the inputs, the normalized matrix was assessed through the consistency rate (CR), the consensus among specialists (SC), and the geometric consistency index (GCI), proposed by Crawford e Williams (1985). The threshold of CR was 0.10 (APOSTOLOU; HASSELL, 1993; CHEN; YU; KHAN, 2010). Further details about the AHP can be found in Chen, Yu and Khan (2010) and Saaty $(1977,2008)$, and its application in spatial analysis for transportation planning in Sadasivuni et al. (2009).

The solution was georeferenced to enable spatial analysis, visualization, clear and comprehensive understanding. Two Integrated Cost-Opportunity Surfaces (ICOS) were generated as resulting from SMCA processes: [ICOS - A] with weighted criteria based on the logistic experts' opinion, determined by the AHP, and [ICOS $-B]$ that favored the social and environmental perspectives. Details about the ICOS-B cost-opportunity surface is available in section 3.3-Scenario Settings. In short, the analysis was computed in a Geographic Information System (GIS). The municipalities were classified to present the best-feasible alternatives to locate new DPs.

Each ICOS represents the weighted sum of the criteria (Equation 2). By following the hierarchy established in the AHP, an ICOS-like calculation method was used for each criterion to compute the sub-criteria. An exception was the environmental criterion, computed upon conditional overlap. The buffer zones, urban areas, and Environmental Protected Areas (EPA) must be mandatorily avoided by this type of enterprise. Thus, there should be no weighting for these sub-criteria when computing the environmental criterion.

$$
\operatorname{ICOS}\left(x_{i}, y_{i}\right)=\sum_{j=1}^{n} P_{n} \times C_{n}\left(x_{i}, y_{i}\right)
$$

Where: ICOS $\left(x_{i} y_{i}\right)=$ value of the Integrated Cost-Opportunity at point i with coordinates $\left(x_{p}, y_{i}\right)$.

$$
\begin{aligned}
& P_{n}=\text { weight of the criterion } n \text { as determined by AHP. } \\
& C_{n}\left(x, y_{i}\right)=\text { value of the criterion } n \text { at coordinate }\left(x, y_{i}\right) \text {. }
\end{aligned}
$$

The Sensitivity Analysis (SA) of the SMCA results considered the social and environmental criteria using the One-Factor-At-A-Time method (OAT) (CHEN; YU; KHAN, 2013; DANIEL, 1958). The goal was to assess the strength of these criteria and the possible impact of socio-environmental prioritization over the other traditional criteria. For each criterion, the weights ranged from 0 to $100 \%$ with increments of $10 \%$, while the other criteria had the proportion of their weight maintained.

\subsection{LOCATION-ALLOCATION PROBLEM (LAP)}

Alike the SMCA, the LAP was also developed on a GIS platform, but based on vector data architecture. The problem was built on a GIS network with connectivity defined in two groups: highways and railways. The network topology has been corrected and validated. Five rules have been specified for the network: two of them related to cost (the length of the section, and the type of road); one related to the hierarchy according to the function class of the road (railway: 1; highways and primary collectors: 2; secondary collectors: 3; local roads: 4); and the last two related to preference (one for rail-based cargo transit and the other for avoiding traffic on local roads).

The input values of the demand points were fed from the corresponding cost-opportunity surface per scenario. Thus, the LAP solution considered the decision rules defined for the network, and also the weighted demand of economic, logistic, social, environmental, and competition criteria. 94 points were selected along with the network as candidates for the location of the new facilities. 
The DP candidate points were distributed in all the mesoregions of the state, being preferably road-rail connections.

Next, the PLA solver was formulated as a p-median problem, where problem consists in locating $p$ logistic facilities (medians) in a network, regarding the compromise in minimizing the total sum of the distances of each demand node to its nearest median (CHRISTOFIDES; BEASLEY, 1982; HAKIMI, 1964; TEITZ; BART, 1968). The goal of the solution was to attend as many demand points as possible. The solver used heuristic techniques, because the solution space, for a mathematical solution, grows until becomes extremely large. Thus, the solver built an Origin-Destination (OD) cost matrix. Next, the edition of Hillsman (HILLSMAN, 1984) was applied to edit the matrix. To refine the solution, a set of semi-randomized solutions was generated and the solver applied a vertex substitution heuristic (TEITZ; BART, 1968). Finally, a GRASP meta-heuristic (FEO; RESENDE, 1995; LORENA et al., 2001), returned the best solution out of a group of good solutions.

\subsection{SCENARIOS SETTINGS}

Four scenarios were defined in this investigation. Six facility locations were selected out of the 94 candidates for each of the four scenarios to meet the 79,535 points of demand. In short, these scenarios integrate different combinations of consideration/no consideration of existing DP with the computed SMCA cost-surfaces, as follow:

- Scenario 1: No existing DP + ICOS-A (AHP weighted criteria);

- Scenario 2: No existing DP + ICOS-B (socio-environmental prioritization);

- Scenario 3: Existing-mandatory DP + ICOS-A (AHP weighted criteria);

- Scenario 4: Existing-mandatory DP + ICOS-B (socio-environmental prioritization);

Two scenarios ( 2 and 4 ) had socio-environmental prioritization. Environmental prioritization was carried out with a view to minimizing impacts on the environment and reducing project efforts by avoiding environmentally sensitive areas (MONTAÑO et al., 2012). The favoring of social criteria pushes the choice of the new DP to serve as an instrument that stimulates regional development by focusing on the generation of jobs and the improvement of social indicators. The weights of the social and environmental criteria were arbitrarily set at $30 \%$ each. The other three criteria had their weightadjusted keeping the proportion determined by the AHP.

To assess the location of the existing DP, the model was executed without considering these facilities (scenarios 1 and 2). Although, in reality, all existing DPs are mandatory in the solution since the goal of the investigation is to be inclusive and does not consider identifying logistic facilities to be deactivated in the study area.

\section{RESULTS AND DISCUSSIONS}

The SMCA weights as determined by AHP were attested by CR $=0.008$ and $\lambda=5.035$. The resulting $C R$ value $(<0.10)$ indicates acceptable consistency of the input values to the pair-wised comparison matrix (APOSTOLOU; HASSELL, 1993; CHEN; YU; KHAN, 2010). The GCl was equal to 0.03 and the consensus of opinions was $84.6 \%$.

The two integrated cost-opportunity surfaces are shown in Figure 4. ICOS-A (left) considered the weights of the criteria determined by the AHP. On the right side, ICOS-B considers weights set to prioritize the 
socio-environmental standpoints. By comparing the two maps, it can be seen that socio-environmental prioritization reduces the economic burden and, in a certain way, attempts to equalize the regions. However, this prioritization does not change the spatial configuration of the solution, where some regional hubs remain more attractive for the installation of the DP.
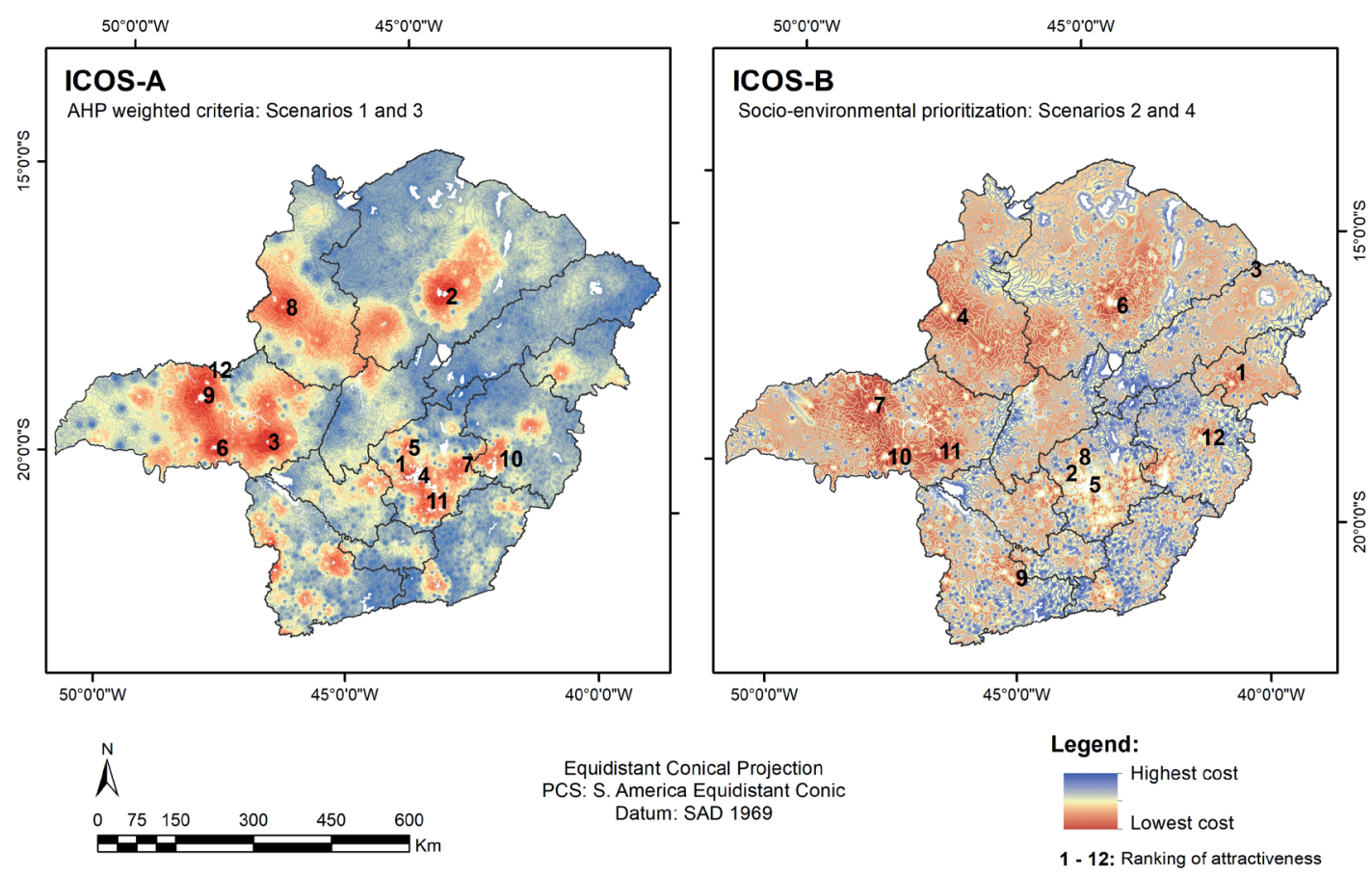

Figure 4 | Integrated cost-opportunity surfaces (ICOS) modeled to located dry ports in Minas Gerais. The model used criteria and weights computed from the Analytic Hierarchy Process (ICOS-A) and prioritization of socio-economic perspectives (ICOS-B), respectively.

Source: Authors' elaboration.

At ICOS-A (scenarios 1 and 3) the maximum opportunity cost for localization of DP was 8.3993 (Arantina, in the south of Minas) and the minimum 2.8601 (Betim). Table 2 shows that the most attractive municipalities in the state are Betim, Montes Claros, and Araxá. However, it is important to consider the existence of DP relatively close to some of these top-attractive municipalities, with special regards to the first and third alternatives, where there will probably be a lot of competition. Thus, findings highlight the municipality of Montes Claros (2nd in the ranking), as it presents high attractiveness and no DP within a radius of $350 \mathrm{~km}$.

Regarding the ICOS-B (scenarios 2 and 4), the costs-opportunity ranged from 9.2408 (Arantina) to 3.4524 (Teófilo Otoni). Thus, the order of classification of the municipalities by attractiveness shown in Table 2 has been changed. However, eight candidates remain as good alternatives in both SMDC approaches: Betim, Montes Claros, Araxá, Belo Horizonte, Sete Lagoas, Uberaba, Paracatu, and Uberlândia. In ICOS-B, Montes Claros falls from the 2 nd to the 6 th position in the classification, due to its proximity to the Lapa Grande State Park and the large urbanized area.

Table 2 | Municipalities that presented high attractiveness for proposing new dry ports, as a result of spatial multi-criteria analysis using traditional macro logistics standpoint with no prioritization of socio-environmental values (ICOS-A).

\begin{tabular}{|c|c|c|c|c|c|c|}
\hline Ranking & Cost & Municipality & Micro region & Meso region & $X$ coord $(m)$ & $Y$ coord $(m)$ \\
\hline 1 & 2,86 & Betim & Belo Horizonte & Metropolitana de BH & $1.571 .640,7$ & $1.248 .247,0$ \\
\hline 2 & 3,07 & Montes Claros & Montes Claros & Norte de Minas & $1.644 .675,2$ & $1.596 .149,6$ \\
\hline
\end{tabular}




\begin{tabular}{|c|c|c|c|c|c|c|}
\hline Ranking & Cost & Municipality & Micro region & Meso region & $X$ coord $(\mathrm{m})$ & $Y$ coord $(\mathrm{m})$ \\
\hline 3 & 3,22 & Araxá & Araxá & $\begin{array}{c}\text { Triângulo / Alto } \\
\text { Paranaíba }\end{array}$ & $1.302 .431,1$ & $1.315 .568,9$ \\
\hline 4 & 3,25 & Belo Horizonte & Belo Horizonte & Metropolitana de BH & $1.590 .851,3$ & $1.251 .391,4$ \\
\hline 5 & 3,30 & Sete Lagoas & Sete Lagoas & Metropolitana de BH & $1.571 .917,2$ & $1.304 .824,2$ \\
\hline 6 & 3,37 & Uberaba & Uberaba & $\begin{array}{c}\text { Triângulo / Alto } \\
\text { Paranaíba }\end{array}$ & $1.202 .742,4$ & $1.304 .367,2$ \\
\hline 7 & 3,75 & Itabira & Itabira & Metropolitana de BH & $1.675 .155,0$ & $1.272 .323,9$ \\
\hline 8 & 3,75 & Paracatu & Paracatu & Noroeste de Minas & $1.336 .801,3$ & $1.574 .621,2$ \\
\hline 9 & 3,78 & Uberlândia & Uberlândia & $\begin{array}{c}\text { Triângulo / Alto } \\
\text { Paranaíba }\end{array}$ & $1.177 .431,2$ & $1.405 .099,9$ \\
\hline 10 & 3,83 & $\begin{array}{c}\text { Santana do } \\
\text { Paraíso }\end{array}$ & Ipatinga & Vale do Rio Doce & $1.746 .041,6$ & $1.282 .858,3$ \\
\hline 11 & 3,96 & Itabirito & Ouro Preto & Metropolitana de BH & $1.606 .038,8$ & $1.212 .047,3$ \\
\hline 12 & 3,97 & Araguari & Uberlândia & $\begin{array}{c}\text { Triângulo / Alto } \\
\text { Paranaíba }\end{array}$ & $1.186 .257,2$ & $1.432 .014,4$ \\
\hline
\end{tabular}

Source: Authors' elaboration.

Figure 5 shows the SA of the environmental criterion to the 12 top-attractive candidate localities for the installation of a new DP based on the lowest value in ICOS-A. All localities presented a linear increase in cost, with a consequent reduction in attractiveness. Paracatu (A87) was the alternative that showed the lowest rate of decrease in cost. The few locations (6 out of 94 ) that reduced the cost by increasing the environmental weight are not among the first 12 in the ranking.

Although, the behavior of the SA of the social criterion was different from the environmental one. The results show a small ${ }^{1}$ cost variation and, unlike the environmental criterion, most locations (66) present cost reductions as the weight of the criterion increases. The locations that presented an increase in cost-opportunity already present higher costs before the increase in weight.

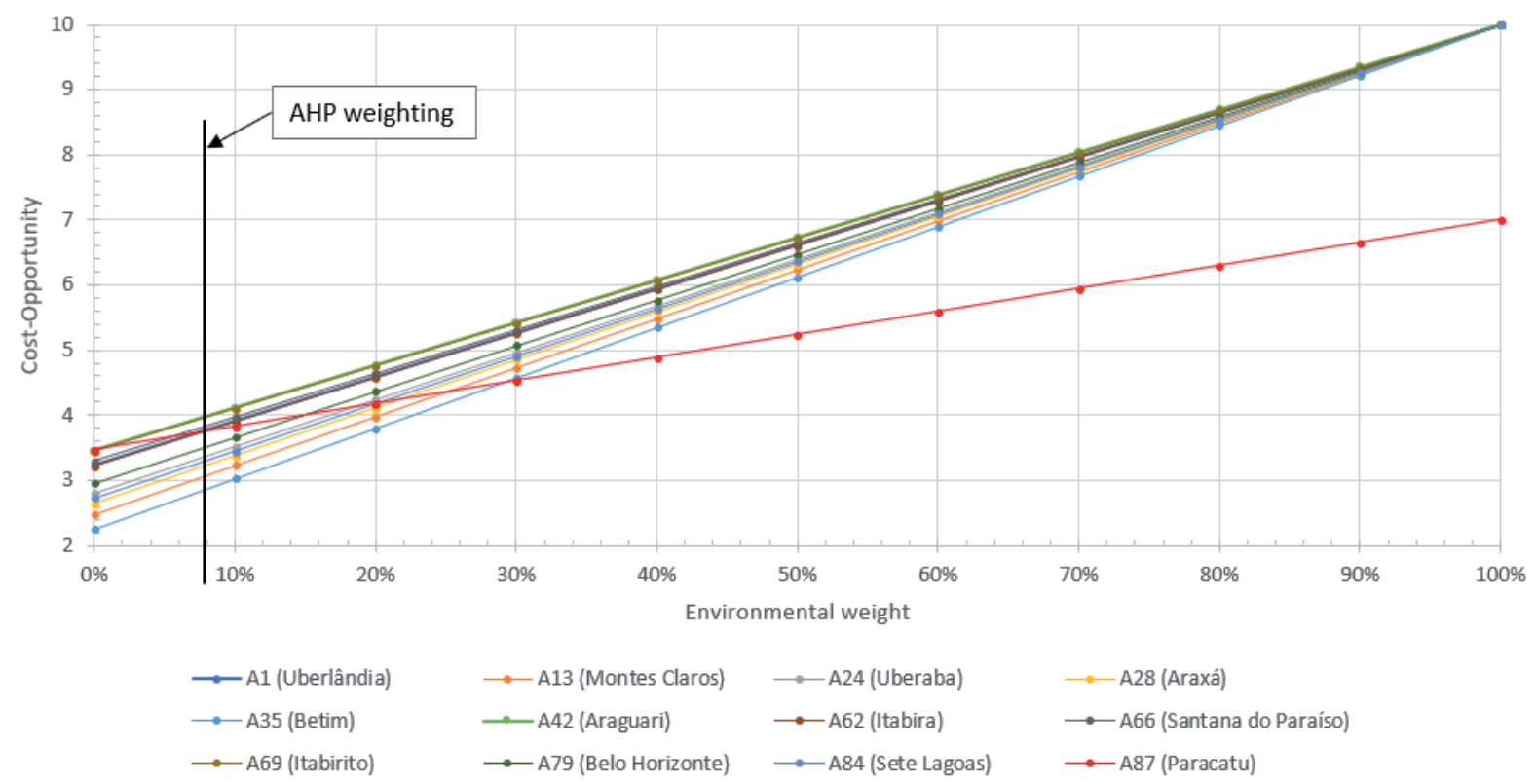

Figure 5 | Sensibility analysis of the environmental criteria with observed variation in cost-opportunity for the 12 municipalities with high attractiveness for new dry ports based on ICOS-A.

Source: Authors' elaboration.

In scenarios 1 and 2, the locations selected were the same due to the similar spatial configuration of ICOS-A and ICOS-B (as showed in Figure 4). Nevertheless, there were only minor differences in the coverage area of each DP. The model pointed to three new DPs to be located in places where 
facilities already exist (Uberlândia, Varginha, and Contagem). Another three were positioned in the municipalities of Paracatu, Teófilo Otoni, and Montes Claros, and it is important to highlight the model choose these places over those that DP already exist, such as Uberaba and Juiz de Fora.

Indeed, the results point to the logistic deficiency in the north of the state (North, Northwest, Jequitinhonha, and Mucuri mesoregions). Despite the demand and consequently potential for installation, there is neither DP installed nor operating in these regions. Furthermore, due to the gravitational characteristic of the LAP, the model resulted in a more balanced spatial distribution of the DP than the current distribution. The coverage area of each DP was very similar to the area of the others. Scenarios 3 and 4, where five existing DP were mandatorily included, the model resulted in a single addition. Thus, Montes Claros was chosen as the best solution in both scenarios. Despite the relative drop in attractiveness in socio-environmental prioritization scenarios, Montes Claros was selected in the LAP due to its key-strategic position (IBGE, 2008). The municipality can serve a wide region not yet served through customs terminals. Notwithstanding, in these two scenarios, one of the mandatory locations (Uberaba) was only accessed by demand points nearby.

Figure 6 illustrates the locations that were selected for new DPs with their respective coverage areas. Due to the close similarity of the results between scenarios 1 and 2, and also between 3 and 4, to simplify the presentation, only the results from scenarios 2 and 4 are presented.

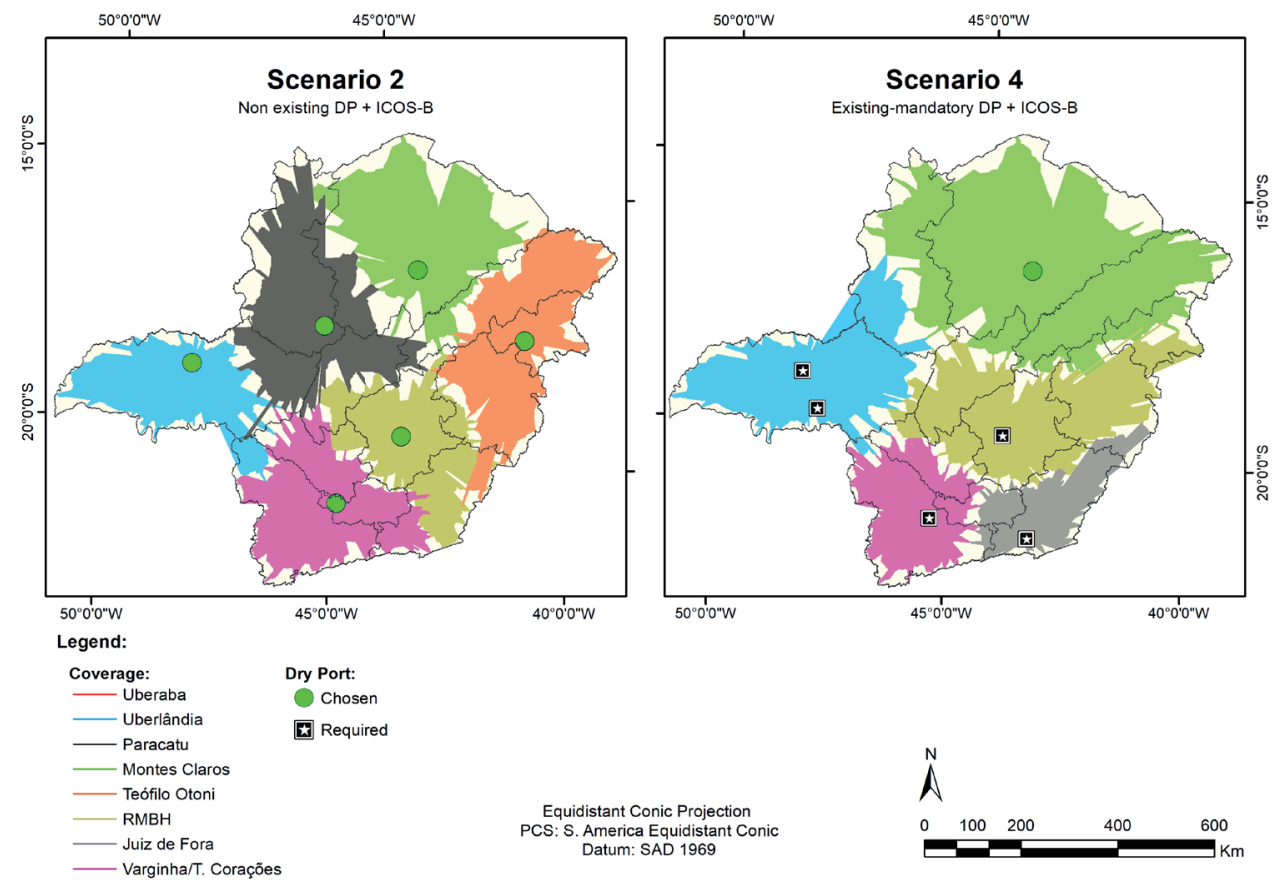

Figure 6 | Dry ports and their respective LAP coverage areas within the state of Minas Gerais as resulting from the two scenarios that prioritized socio-environmental perspectives.

Source: Authors' elaboration.

Regarding the characteristics of Montes Claros, an important factor that influenced the choice is the concentration of export and import activities in the northern part of the state, some of them converging in Montes Claros and vicinity. According to BRASIL (2018), almost 99\% of the FOB export value of the mesoregion in the north of Minas Gerais comes from only seven municipalities. Montes Claros alone is responsible for 49.9\% (2017) and 38.3\% (2018) of the total value exported by the mesoregion (BRASIL, 2018).

The results of this study corroborate to IBGE (2008) that established Montes Claros as Level B Regional Capital due to its rationality and area of influence in the state of Minas Gerais. According to the results (Figure 6) and with IBGE (2008), in addition to the northern mesoregion of Minas, Montes Claros also influences the northwestern, Vale do Jequitinhonha and Mucuri mesoregions. 
The integration of two methods for geolocation was key important to the quality of the results if compared to each method individually. Instead, if the location methods considered only SMCA, the municipality of Betim would show up preference over Montes Claros. However, the Metropolitan Region of Belo Horizonte, where Betim is located, is already served by a DP. On the other hand, the LAP solution without weighting the cost-opportunity would be restricted to the optimization of the number of demand points served. Consequently, the importance of the social and environmental dimensions would probably be neglected. In addition, bringing this type of analysis early in the planning stage can facilitate the environmental licensing process, which requires the assessment of environmentally viable local alternatives (MONTAÑO et al., 2012).

The study reveals the consequences of a critical fact: the productive investment projects as directed to Minas Gerais between 2004 and 2014 were strongly spatial concentrated (MINAS GERAIS, 2015). Only four of the seventeen State Development Territories accounted for $70 \%$ of the investment intentions. Traditionally, the preference is to the most dynamic regions in detriment of the historically problematic areas regarding the environmental, economic, and social standpoints. In other words, state development transportation-related policies sanctioned a certain pre-existing productive and spatial configuration (MINAS GERAIS, 2015). It is necessary to overcome this scenario of regional inequality through SSED across the state.

\section{CONCLUSION}

Dry ports are alternatives for mitigating congestion and social conflicts in primary logistic areas, by reducing transportation costs, speeding up the process, and reducing environmental impacts. However, DP has been a subject traditionally limited to the area of transport. To bring the subject to a broader audience, this study presents subsidies to formulate a more comprehensive and participatory planning proposal involving DP. The investigation shows the social and environmental factors, which character often overlooked in the Cartesian view of traditional transportation engineering, that should be considered in the decision-making process for choosing the location for new facilities. Accordingly, the greatest benefit for all stakeholders can be achieved, promoting sustainable regional development.

As expected, by using two well-established methods for locating facilities drove different results for each method individually. However, the objective of the investigation was to integrate the two methods into a model. Thus, the contribution of the article was to demonstrate the gain achieved by the integration of modern and consolidated methods of decision support in transport planning. With that, it was possible to affirm that the research produced a model optimized from a logistical point of view, and at the same time inclusive since it met social and environmental demands.

Despite Minas Gerais has the most extensive road network in the country, the presents enormous regional disparities regarding transportation strategy and infrastructures. The results showed the northern mesoregions (North, Northwest, Jequitinhonha, and Mucuri) need for inland port and customs services. The study used multidimensional methods to assure that places with high potential are not neglected, as well as to assure the installation of new DP neither stress the inequality of infrastructure nor accentuates environmental and social issues. Thus, the locational analyzes developed from different scenarios resulted in the convergence of Montes Claros as a priority location for the installation of DP.

The authors understand the investigation achieved its major objective. The proposed methodology was broken down to be elucidative and to support the discussion. Moreover, it provided the identification of the most suitable locations for installing DP in the state of Minas Gerais, considering inputs from logistical, social, environmental, economic, and competition elements. This study is original and certainly can be enhanced. Future work may incorporate more criteria, evaluate the model's performance metrics, compare the results with other methods, and even apply a spatially explicit sensibility analysis. 


\section{ACKNOWLEDGMENTS}

The authors acknowledge CAPES, CNPq, and FAPEMIG for funding this research. We also would like to thank colleagues Vanilson Couto and Ana Ísis Moura for their contributions to the work.

\section{NOTES}

1 Average variation of the cost (mean difference among the cost at $0 \%$ weight and $100 \%$ weight of all alternatives) in the sensibility analysis of social perspective is 1.11 versus 4.32 of the environmental one.

\section{REFERENCES}

ANTAQ. Anuário Antaq. Disponível em: <http://web.antaq.gov.br/Anuario/>. Acesso em: 20 nov. 2018.

APOSTOLOU, B.; HASSELL, J. M. An empirical examination of the sensitivity of the analytic hierarchy process to departures from recommended consistency ratios. Mathematical and Computer Modelling, 1993.

AWAD-NÚÑEZ, S. et al. How should the Sustainability of the Location of Dry Ports be Measured? Transportation Research Procedia, v. 14, n. 2016, p. 936-944, 2016 a.

AWAD-NÚÑEZ, S. et al. A Methodology for Measuring Sustainability of Dry Ports Location Based on Bayesian Networks and Multi-criteria Decision Analysis. Transportation Research Procedia, v. 13, n. 2016, p. 124-133, 2016 b.

BARBOZA, P. D.; VIEIRA, J. G. V. Análise de decisão multicritério aplicada na seleção de investimento em armazenagem de soja em grão. Produto \& Produção, v. 15, n. 2, p. 24-45, 2014.

BOLTURK, E. et al. Multiattribute Warehouse Location Selection in Humanitarian Logistics Using Hesitant Fuzzy AHP. International Journal of the Analytic Hierarchy Process, v. 8, n. 2, 2016.

BRASIL. Lei N. 12.651. Dispõe sobre a proteção da vegetação nativa; altera as Leis n. 6.938, de 31 de agosto de 1981, 9.393, de 19 de dezembro de 1996, e 11.428, de 22 de dezembro de 2006; revoga as Leis n. 4.771, de 15 de setembro de 1965, e 7.754, de 14 de abril de 1989, e a Medida Provisória n. 2.166-67, de 24 de agosto de 2001; e dá outras providências. Brasília, Brasil: Diário Oficial da União - Seção 1 - 28/5/2012, p. 1-32.

BRASIL. Ministério da Indústria, Comércio Exterior e Serviços. Estatísticas de Comércio Exterior. Disponível em: <http://www.mdic.gov.br/comercio-exterior/estatisticas-de-comercio-exterior>. Acesso em: 31 mar. 2018.

BRASIL. Ministério dos Transportes. Base de Dados Georreferenciados PNLT 2010. Brasília (on-line): Ministério dos Transportes, 2014. Disponível em: <https://www.infraestrutura.gov.br/conteudo/2822-base-de-dadosgeorreferenciados-pnlt-2010.html>. Acesso em: 31 jul. 2018.

BRASIL. Resolução Conama 013/1990. Dispõe sobre a área circundante, num raio de 10 (dez) quilômetros, das Unidades de Conservação. Brasília, Brasil: Diário Oficial da União, 28/12/1990, p. 25541.

CHEN, Y.; YU, J.; KHAN, S. Spatial sensitivity analysis of multi-criteria weights in GIS-based land suitability evaluation. Environmental Modelling \& Software, v. 25, n. 12, p. 1582-1591, 2010.

The spatial framework for weight sensitivity analysis in AHP-based multi-criteria decision making. Environmental Modelling \& Software, v. 48, p. 129-140, 2013.

CHINELATO, F. B.; CRUZ, D. B. DE F.; ZIVIANI, F. Made in Brazil: o impacto da infraestrutura logística brasileira nas operações de comércio exterior. Revista Administração em Diálogo - RAD, v. 13, n. 3, 2011.

CHRISTOFIDES, N.; BEASLEY, J. E. A tree search algorithm for the p-median problem. European Journal of Operational Research, v. 10, n. 2, p. 196-204, 1982.

CNT. Pesquisa CNT de Rodovias 2018. CNT | SEST SENAT. Brasília: Confederação Nacional do Transporte, 2018. Disponível em: <http://pesquisarodovias.cnt.org.br/Home>. Acesso em: 10 nov. 2018. 
CRAWFORD, G.; WILLIAMS, C. A note on the analysis of subjective judgment matrices. Journal of Mathematical Psychology, 1985.

DANIEL, C. On Varying One Factor at a Time. Biometrics, v. 14, 1958.

DINWOODIE, J. et al. Sustainable Development of Maritime Operations in Ports. Business Strategy and the Environment, v. 21, n. 2, p. 111-126, 2012.

GERMANO, E. C.; FREIRE JÚNIOR, A. E. A importância do porto seco como facilitador na armazenagem e desembaraço aduaneiro. Revista Fatec Sebrae em Debate: Gestão, Tecnologias e Negócios, v. 04, n. 6, 2017.

GOEPEL, K. D. Implementing the Analytic Hierarchy Process as a standard method for multi-criteria decision making in corporate enterprises - A new AHP Excel template with multiple inputs. Proceedings of the International Symposium on the Analytic Hierarchy Process. Kuala Lumpur: 2013. Disponível em: <https://bpmsg.com/newahp-excel-template-with-multiple-inputs/>. Acesso em: 29 dez. 2018.

GOULIELMOS, A. M. European Policy on Port Environmental Protection. Global Nest Journal, v. 2, n. 2, p. 189-197, 2013.

HAKIMI, S. L. Optimum Locations of Switching Centers and the Absolute Centers and Medians of a Graph. Operations Research, v. 12, n. 3, p. 450-459, 1964.

HILLSMAN, E. L. The p-Median Structure as a Unified Linear Model for Location-Allocation Analysis. Environment and Planning A, v. 16, n. 3, p. 305-318, 1984.

INSTITUTO BRASILEIRO DE GEOGRAFIA E ESTATÍSTICA. Regiões de influência das cidades 2007. Rio de Janeiro, RJ, Brasil: IBGE, 2008. Disponível em: <www.ibge.gov.br>.

INSTITUTO BRASILEIRO DE GEOGRAFIA E ESTATÍSTICA. Censo 2010. Rio de Janeiro, RJ, Brasil: IBGE, 2012. Disponível em: <https://censo2010.ibge.gov.br/>. Acesso em: 6 maio 2020.

INSTITUTO BRASILEIRO DE GEOGRAFIA E ESTATÍSTICA. Downloads Geociências | IBGE. Rio de Janeiro (on-line): IBGE, 2018. Disponível em: <https://www.ibge.gov.br/geociencias/downloads-geociencias.html>. Acesso em: 31 jul. 2018.

JAFFEE, D. 'A Deeper Channel Floats all Boats': the port economy as urban growth engine. Environment and Planning A: economy and space, v. 47, n. 4, p. 783-800, 2015.

KA, B. Application of fuzzy AHP and Electre to China dry port location selection. Asian Journal of Shipping and Logistics, v. 27, n. 2, p. 331-354, 2011.

KOEHLER, P. H. W.; ASMUS, M. L. Gestão ambiental integrada em Portos Organizados: uma análise baseada no caso do porto de Rio Grande, RS - Brasil. Revista da Gestão Costeira Integrada, v. 10, n. 2, p. 53-67, 2010.

LIGMANN-ZIELINSKA, A.; JANKOWSKI, P. Spatially-explicit integrated uncertainty and sensitivity analysis of criteria weights in multicriteria land suitability evaluation. Environmental Modelling and Software, v. 57, p. 235-247, 2014.

LORENA, L. A. N. et al. Integração de modelos de localização a sistemas de informações geográficas. Gestão \& Produção, v. 8, n. 2, p. 180-195, 2001.

LOUREIRO, J. F.; FREITAS, R. R. DE; GONÇALVES, W. Proposta de um método de localização para expansão de um terminal portuário por meio do Analytic Hierarchy Process (AHP). Revista Espacios, v. 36, n. 10, p. 7, 2015.

MAPA, S. M. S.; LIMA, R. DA S. Uso combinado de sistemas de informações geográficas para transportes e programação linear inteira mista em problemas de localização de instalações. Gestão \& Produção, v. 19, n. 1, p. 119-136, 2012.

MEDEIROS, M. C. A geografia do mercado mundial de produtos agroalimentares e o papel do Brasil. Raega - 0 Espaço Geográfico em Análise, v. 31, p. 260, 2014.

MINAS GERAIS. Desenvolvimento econômico e social sustentável de Minas Gerais: redução das desigualdades sociais e regionais. Plano Mineiro de Desenvolvimento Integrado (PMDI). Belo Horizonte, MG: Governo de Minas Gerais, 2015. Disponível em: <https://www.mg.gov.br/conteudo/transicao/pmdi/pmdi>. 
MITCHEL, A. The ESRI Guide to GIS analysis. Redlands: ESRI Press, 2005. v. 2

MONTAÑO, M. et al. Integração de critérios técnicos, ambientais e sociais em estudos de alternativas locacionais para implantação de aterro sanitário. Engenharia Sanitária e Ambiental, v. 17, n. 1, p. 61-70, 2012.

NG, A. K. Y.; PADILHA, F.; PALLIS, A. A. Institutions, bureaucratic and logistical roles of dry ports: the Brazilian experiences. Journal of Transport Geography, v. 27, p. 46-55, 2013.

NGUYEN, L. C.; NOTTEBOOM, T. A Multi-Criteria Approach to Dry Port Location in Developing Economies with Application to Vietnam. The Asian Journal of Shipping and Logistics, v. 32, n. 1, p. 23-32, 2016.

OLIVEIRA, D. S. et al. Expansão Portuária, Desenvolvimento Municipal e Alterações Ambientais no Brasil: desafios para a gestão costeira. Revista de Gestão Costeira Integrada, v. 13, n. 1, p. 79-87, 2013.

PNUD; FJP; IPEA. Atlas do Desenvolvimento Humano no Brasil. Disponível em: <http://atlasbrasil.org.br/2013/>. Acesso em: 15 jun. 2020.

RAHMAN, M. A. et al. An integrated study of spatial multicriteria analysis and mathematical modeling for managed aquifer recharge site suitability mapping and site ranking at Northern Gaza coastal aquifer. Journal of Environmental Management, v. 124, p. 25-39, 2013.

ROSO, V.; WOXENIUS, J.; LUMSDEN, K. The dry port concept: connecting container seaports with the hinterland. Journal of Transport Geography, v. 17, n. 5, p. 338-345, 2009.

SAATY, T. L. A scaling method for priorities in hierarchical structures. Journal of Mathematical Psychology, 1977.

SAATY, T. L. Decision making with the analytic hierarchy process. International Journal of Services Sciences, v. 1, n. 1, p. 83-98, 2008.

SADASIVUNI, R. et al. A transportation corridor case study for Multi-criteria Decision Analysis. Proceeding of ASPRS 2009 Annual Conference. Baltimore, USA: ASPRS, 2009.

SINAY, M. C. F.; CARVALHO, S. D.; BRAGA, I. L. A Importância da Inclusão da Variável Ambiental na Gestão Portuária. Revista de Administração, Sociedade e Inovação, v. 3, n. 2, p. 124-135, 2017.

SNYDER, J. P. Map Projections: a working manual. Washington, DC, USA: United States Government Printing Office, 1987.

SOPHA, B. M. et al. Urban distribution center location: combination of spatial analysis and multi-objective mixedinteger linear programming. International Journal of Engineering Business Management, v. 8, p. 1-10, 2016.

TEITZ, M. B.; BART, P. Heuristic Methods for Estimating the Generalized Vertex Median of a Weighted Graph. Operations Research, v. 16, n. 5, p. 955-961, 1968.

WANKE, P. F.; HIJJAR, M. F. Exportadores brasileiros: estudo exploratório das percepções sobre a qualidade da infraestrutura logística. Produção, v. 19, n. 1, p. 143-162, 2009. 